\title{
A SIMPLIFIED AND CHEAPEST METHOD FOR THE DIAGNOSIS OF SICKLE CELL USING WHOLE BLOOD PCR AND RFLP IN NEPAL Giri Raj Tripathi*
}

\begin{abstract}
Sickle cell anemia is a serious genetic health problem dominated in Tharu community of western Nepal. Molecular methods like PCR and RFLP are the best method to identify Sickle $c$ ell anemia trait. Molecular analysis needed many steps and expensive chemicals and Kits. The aim of this research was to develop a simple and cheapest method to process from whole blood sample for the polymerase chain reaction (PCR) and restriction fragment length polymorphism (RFLP) without the use of expensive reagents and Kits. In this study molecular identification of sickle cell traits is subjects using whole blood PCR and RFLP were carried out. Venous blood samples collected from 800 individuals were provided by Nepal Health Research Council (NHRC). All the obtained samples were frozen at $-80^{\circ} \mathrm{C}$, and then rapidly thawed at $37^{\circ} \mathrm{C}$. Then the samples were transferred to $2 \mathrm{ml}$ eppendrof tube and boiled for 10 minutes in distilled water and centrifuged at $12000 \mathrm{rpm}$ for 2 minute. The supernatant was then used directly for PCR and RFLP. For comparison, purified DNA from the QIAGEN genomic DNA extraction kit was used as control. PCR/RFLP results using the whole blood boiling method was qualitatively similar to DNA extracted by using commercial Kits. The research demonstrates that whole blood PCR and RFLP method is simple and cheaper way for molecular diagnosis of sickle cell traits in human.
\end{abstract}

Key Words: Sickle cell anemia, whole blood, PCR, RFLP, Gel electrophoresis.

\section{INTRODUCTION}

Sickle cell disease known as Haemoglobin SS (HBS) disease is caused by a mutation in the beta globin gene cluster. Such mutation results in the production of an abnormal version of the beta chain of haemoglobin, which carry low oxygen through the body. The beta globin gene is located on the short arm of chromosome 11. It is a member of the globin gene family, a group of genes involved in oxygen transport. A single nucleotide change (A to $\mathrm{T}$ ) in the beta globin chain causes the substitution of amino acid glutamine to valine causes the disorder sickle cell anemia. Homozygous $\mathrm{HbS}$ is a serious hemoglobinopathy found

Dr. Tripathi is Reader in Biotechnology at Central Department of Biotechnology, Truffle Research Programme, Tribhuvan University, Kirtipur, Kathmandu, Nepal. 
exclusively in the Tharu population of western Nepal. About 18 percent Tharu people are affected with sickle cell anemia, making one of the most prevalent genetic disorders who are ranks first as the inherited sickle cell endemic population in Nepal (Tripathi, G.R., 2015).

Cellulose acetate electrophoresis is a cheap method to diagnose the sickle cell disease which is commonly use in Central Hospital of Nepal (Adhikari, et al., 2003). This method has demerits where quantitative densitometry of abnormal hemoglobins is inaccurate at low concentrations ( $\mathrm{HbA} 2, \mathrm{HbF})$. Cellulose acetate electrophoresis is unreliable techniques since a great percentage of hemoglobin in newborns is $\mathrm{HbF}$ (Bender TR and Hobbs, LA, 2003).

Molecular techniques like Polymerase chain reaction (PCR), restriction fragment length polymorphism (RFLP), hybridization, and DNA sequencing are the best methods for the diagnosis of sickle cell and other human genetic diseases. Molecular methods require extraction and purification of DNA from biological samples such as blood, tissues, or body fluids. DNA extraction and purification process needed a number of expensive chemicals, reagents, Kits and equipments (Gross-Bellard M et al. 1973; Sambrook, A, 1989). With the advancement of molecular biology many attempts has been carried out to developed and simplify the procedure for DNA extraction and purification that maintain the quality and purity of the DNA which is suitable for the molecular processing like PCR and RFLP (Miller et al., 1988; Ferre et al., 1989; Shibata et al., 1988; Smith et al., 2003). The chemicals used in DNA extraction needed different chemicals like lysozyme, proteinase $\mathrm{K}$ and Tween 20 which breaks and lyses the cells (Proteous et al., 1994; Tell et.al., 2003, Zhu et al., 2005; Merk et al., 2006; Orsini et al., 2001). In addition, various physical processes like heating, cooling, freezing etc. (Jose et al., 2006; Dederich et al., 2002; Banik et al., 2003; Woo et al., 2000) are also essential. Both combined physical and chemical methods have been used for the extraction of DNA (Jose et al., 2006; Zhu et al., 2005; Tell et al., 2003, Dederich et al., 2002). The DNA extraction procedures are laborious, time consuming and expensive. Now a days, faster and simpler methods involved commercial Kits have been developed and using by almost diagnostic and research centers. These Kits are costly and require several steps and reagents (Smith et al., 2003; Mercier, et al., 1990).

In this study we developed a simple and cheap method for direct PCR and RFLP from processed whole blood without using expensive commercial DNA extraction Kit and reagents. The extracted DNA from commercial Kits was tested by PCR and RFLP in parallel with whole blood DNA. 


\section{MATERIALS AND METHODS \\ SAMPLES COLLECTION}

Three $\mathrm{ml}$ of venous blood sample was taken from eight hundred fertile aged women of western Nepal. All the blood samples were collected by the Nepal Health Research Council (NHRC) and sent to Truffle Research Laboratory, for sickle cell diagnosis using molecular methods. Blood samples were obtained in EDTA tubes containing potassium EDTA as an anticoagulant, and the samples were stored at $-20^{\circ} \mathrm{C}$ for the further use. The samples were analyzed at the Molecular Biology laboratory of the Truffle Research Program, Tribhuvan University, Kathmandu, Nepal.

\section{DNA EXTRACTION FROM KIT}

DNA was extracted from individual blood sample tubes provided by NHRC using QIAGEN genomic DNA Extraction Kit following the manufacturer's instructions.

\section{DNA EXTRACTION FROM WHOLE-BLOOD SAMPLES}

Blood samples were thawed at $37^{\circ} \mathrm{C}$ and $10 \mu 1$ of sample was taken and mixed with $490 \mu \mathrm{l}$ of autoclaved deionized double distilled water in a $2 \mathrm{ml}$ Eppendorf tube. The mixture taken in Eppendorf tube was capped tightly and left for incubation at room temperature for 10 minute. Then the samples tubes were boiled in distilled water pot for about 10 minutes in a gas stove. The boiled blood samples were centrifuged at 12,000 rpm for $2 \mathrm{~min}$. Finally, the $2 \mathrm{ul}$ of clear supernatant was taken for PCR.

\section{Polymerase Chain Reaction}

One microliter of extracted DNA from QIAGEN Kit and 2ul of processed supernatants from the whole-blood were taken separately in PCR tubes. All the individual samples taken in PCR tubes were mixed with prealiquoted 5x PCR master Mix (NEB, USA) containing 0.2 units of Taq DNA polymerase, $10 \mathrm{mM}$ Tris- $\mathrm{HCl}(\mathrm{pH} 8.8), 50 \mathrm{mM}(\mathrm{KCl}), 1.5$ $\mathrm{mM} \mathrm{MgCl} 2,0.2 \mathrm{mM}$ of each of the four deoxynucleotide triphosphates (dATP, dCTP, dGTP, dTTP), 0.08\% IGEPAL, 5\% glycerol, and $0.05 \%$ Tween 20. Ten picomoles of each of the following two primers were then added to this mixture of 1: 5'- ACA CAA CTG TGT TCA CTA GC -3' (nucleotides 1576-1595); and 2: 5'-CAA CTT CAT CCA CGT TCA CC3' (nucleotides 1486-1505) designed from NCBI Gene Bank accession no CH471064. These primers flank a 110-bp DNA fragment of HBB gene which is present in chromosome 11 of Homo sapines. This part was chosen because it contains the site of mutation nearly at middle of the PCR amplification, which made single band with $D d e$ I restriction enzyme digestion. The PCR mixture was then denatured at $95^{\circ} \mathrm{C}$ for $3 \mathrm{~min}$ and followed by 35 cycles of successive alternating temperatures as follows: 
denaturation step at $95^{\circ} \mathrm{C}$ for $30 \mathrm{sec}$, annealing step at $58^{\circ} \mathrm{C}$ for $30 \mathrm{sec}$, and extension step at $72^{\circ} \mathrm{C}$ for $1 \mathrm{~min}$. A final extension was step at $72^{\circ} \mathrm{C}$ for $5 \mathrm{~min}$. The PCR was performed in a programmable Thermal Cycler (T10 BioRad, USA). Agarose gel electrophoresis was carried out in $1.5 \%$ agarose gel in Tris-acetate-EDTA (TAE) buffer $(40 \mathrm{mM}$ Tris $\mathrm{pH} 7.6$, $20 \mathrm{mM}$ acetic acid, $1 \mathrm{mM}$ EDTA pH 8.0) containing $0.5 \mu \mathrm{g} / \mathrm{ml}$ of ethidium bromide to enhance visualization of DNA bands under UV light. The PCR products were mixed with $3 \mu 1$ of $6 \mathrm{X}$ loading buffer, loaded on as above prepared agarose gel and run on the electrophoresis machine (BioRad, USA) at $70 \mathrm{~V}$. The size marker $100 \mathrm{bp}$ DNA ladder was loaded at the first slot of the well.

\section{RESTRICTION FRAGMENT LENGTH POLYMORPHISM}

Twenty microliters of the PCR product were mixed with $1 \mu$ of the Dde I restriction enzyme $(10,000 \mathrm{U} / \mathrm{ml}$ from NEB), $5 \mu$ l of buffer $(10 \mathrm{x}$ cut smart buffer, NEB), and $24 \mu \mathrm{l}$ of PCR grade autoclaved millique water was mixed to make $50 \mu \mathrm{l}$ final volume and incubated at $37^{\circ} \mathrm{C}$ for $16 \mathrm{~h}$. PCR products, after restriction digestion with the Dde I, were subjected to electrophoresis on a ethidium bromide incorporated $2 \%$ agarose gel. These DNA bands were visualized by exposure to UV light in a gel documentation system (BioRad, USA).

\section{COMPARISON WITH PCR AND RFLP BY DNA EXTRACTION WITH COMMERCIAL KIT AND WHOLE-BLOOD DNA}

For comparison purposes, positive control was taken from DNA extracted using commercial DNA extraction Kit (QIAGEN) method. One hundred nano-grams of the purified DNA from each extraction method were used to perform PCR and RFLP analyses, using the procedures as described above.

\section{RESULTS}

In this experiment non sickle cell carriers' DNA was used as a negative control which has single restriction site when digested with the restriction enzyme Dde I. After the restriction digestion and gel electrophoresis the band size was occurred at around $\sim 55 \mathrm{bps}$. If the person is sickle cell carrier: Homozygous trait $(\mathrm{S} / \mathrm{S})$ has single band at the size of 110 base pairs and Heterozygous trait (A/S) has two bands with the size of 110 and $\sim 55$ base pairs.

A picture of agarose gel electrophoresis of RFLP products from whole-blood PCR method and the DNA extracted from commercial kits is shown in figure 1. Results of two cases are included, but all cases this experiment gave similar results. The expected PCR amplified product size obtained with specific primers for sickle cell mutation before digestion with Ddel I enzyme was 110 bp. The DNA extracted by our simplified 
method, and commercial QIAGEN genomic DNA extraction kits gave similar result in PCR amplification and RFLP analysis (Fig.-1).

In RFLP analysis, Ddel I restriction endonuclease was used to cleave the PCR amplicons of the HBB gene. The Dde I restriction enzyme managed to cut the PCR amplicons produced from the whole blood by the present method (Fig.-1). After cutting, outcome fragments were 110, 54 and $56 \mathrm{bp}$ in the heterozygous case (A/S), and $110 \mathrm{bp}$ in the homozygous case $(\mathrm{S} / \mathrm{S})$ Table-1. A similar pattern was obtained whether the DNA samples were extracted by the commercial kits. Cutting was successful in all the samples. In addition, the cutting patterns were as expected in each case whether it had the mutation or not.

Table-1: Mutation Abolishes Restriction Site

\begin{tabular}{|c|c|c|}
\hline \multicolumn{3}{|c|}{ PCR Product Fragment Size 110 bp } \\
\hline \multicolumn{3}{|c|}{ Fragment Sizes After Dde I Digestion } \\
\hline $\mathbf{A} / \mathbf{A}$ & $\mathbf{A} / \mathbf{S}$ & S/S \\
\hline $54+56 \mathrm{bp}$ & $110+54+56 \mathrm{bp}$ & $110 \mathrm{bp}$ \\
\hline
\end{tabular}

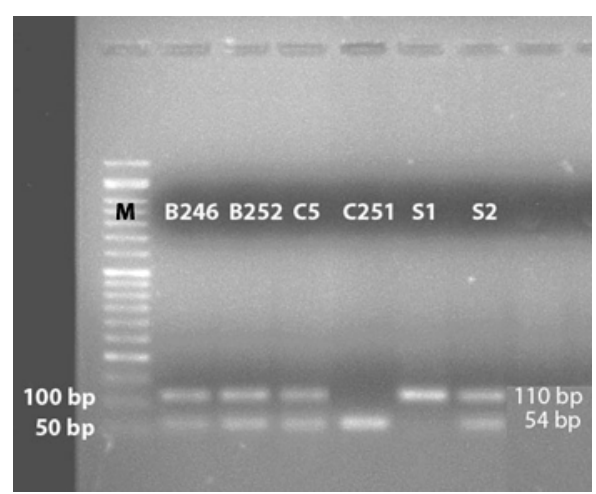

Fig.-1: Agarose gel electrophoresis of a typical Sickle cell genotype analysis of PCR product digested with Dde I restriction enzyme (NEB). Lane $\mathrm{M}$ is molecular weight marker of 100bp size. Lanes B246, B252, C5, S2 are the Heterogygous trait of the Sickle cell DNA with A/S genotype. Lane S1 is a homozygous sickle cell trait with S/S genotype and Lane 251 is A/A genotype. In this figure Lane no B246, B252, and C5 were DNA extracted from whole-blood boiling system and Lane C251, S1, S2 are the Control DNA extracted from commercial genomic DNA extraction Kit (QIAGEN).

\section{DISCUSSION}

In this research we attempted and developed the simplified procedure to decrease cost for the DNA extraction without affecting the quality and sample throughput. The commercial DNA extraction Kits are 
expensive and needed number of chemicals, reagents and steps for DNA extraction and purification of DNA. Whole blood boiling method can denature tissue (Coates et al., 1987), and pretreatment step for DNA extraction can be use for different organisms like fungi, plants and animals (Rudbeck et al., 1998). Heating blood at $95^{\circ} \mathrm{C}$ for $15 \mathrm{~min}$ had been cytolyse cells (Panaccio et al., 1993).

The DNA extraction method we used are freezing and heating, exposure of sample to hypotonic environment with boiling in water that ruptured cell membrane and released the DNA. Analyses of DNA samples obtained from whole blood processed method showed that both PCR and RFLP results were same as genomic DNA extracted from the commercial Kits. The method we used in this study does not require any additional reagent except deionized distilled water used to challenge cells in a hypotonic situation that induced cytolysis further. Also, water diluted the hemoglobin content and thus might have reduced its inhibitory effect on PCR (Panaccio et al., 1993).

The present method is also suitable for whole blood samples stored at $-20^{\circ} \mathrm{C}$ for several months. Other areas of potential application of this simple procedure may be useful for DNA sequencing, hybridization techniques, real-time PCR, and PCR, production of DNA amplicons of large sizes and processing of other biological specimens such as culture cells, hair, body fluids, and bacteria.

\section{CONCLUSION}

DNA processing from whole blood PCR method is simple, cheap, quick method for directly use in PCR and RFLP techniques. The results compared with DNA extracted from commercial Kits and whole blood processed method has no difference. Another benefit is whole blood processed PCR method reduce DNA extraction Kits cost about NRs 500 per sample which can be more affordable for the poor people to diagnosis the sickle cell trait using molecular method.

\section{WORKS CITED}

Adhikari, R.C., Shrestha, T., Shrestha, R., Subedi, R., Parajuli, K. \& Dali, S. (2003). SICKLE CELL DISEASE-CASE REPORTS. Journal of Nepal Medical Association, 42(145), 36-38.

Banik, S., Bandyopadhyay, S. \& Ganguly, S. (2003). Bioeffects of microwave. A brief review. Bioresour Technol. 87:155-159.

Bender, T.R. \& Hobbs, L.A. (2003). Haemogloginopathy diagnosis in Neonates. Genet Test. 7(5): 224-229.

Coates, P.J., Hall, P.A., Butler, M.G. \& D’Ardenne, M.G. (1987). Rapid technique of DNA-DNA in situ hybridization on formalin fixed tissue sections using microwave incubation. J Clin Pathol. 40: 865-869. 
Dederich, D.A., Okwuonu, G., Garner T., Denn, A., Sutton, A., Escotto, M., Martindale, A., Del- gado, O., Muzny, D.M., Gibbs, R.A. \& Metzker, M.L. (2002). Glass bead purification of plasmid template DNA for high throughput sequencing of mammalian genomes. Nucleic Acids Res. 30: e32.

Ferre, F. \& Garduno, F. (1989). Preparation of crude cell extract suitable for amplification of RNA by the polymerase chain reaction. Nucleic Ac- ids Res. 17:2141.

Gross-Bellard, M., Oudet, P. \& Chambon, P. (1973). Iso- lation of highmolecular-weight DNA from mammalian cells. Eur J Biochem. 36: 32-38.

Jose, J.J. \& Brahmadathan, K.N. (2006). Evaluation of simplified DNA extraction methods for EMM typing of group A streptococci. Indian J Med Microbiol. 24: 127-130.

Mercier, B., Gaucher, C., Feugeas, O. \& Mazurier, C. (1990). Direct PCR from whole blood, without DNA extraction. Nucleic Acids Res. 18: 5908.

Merk, S., Meyer, H., Greiser-Wilke, I., Sprague, L.D. \& Neubauer, H. (2006). Detection of Burkholderia cepacia DNA from artificially infected EDTA-blood and lung tissue comparing dif- ferent DNA isolation methods. J Vet Med B Infect Dis Vet Public Health. B53: 281-285.

Miller, S.A., Dykes, D.D. \& Polesky, H.F. (1988). A simple salting out procedure for extracting DNA from human nucleated cells. Nucleic Acids Res. 16: 1215.

Orsini, M. \& Romano-Spica, V. (2001). A microwave- based method for nucleic acid isolation from environmental samples. Lett Appl Microbiol. 33: 17-20.

Panaccio, M., Georgesz, M. \& Lew, A. (1993). FoLT PCR: a simple PCR protocol for amplifying DNA directly from whole blood. Biotechniques. 14: 238-243.

Porteous, L.A., Armstrong, J.L., Seidler, R.J. \& Wa- trud L.S. (1994). An effective method to extract DNA from environmental samples for polymerase chain reaction amplification and DNA fin- gerprint analysis. Curr Microbiol. 29: 301-307.

Rudbeck, L. \& Dissing, J. (1998). Rapid, simple alkaline extraction of human genomic DNA from whole blood, buccal epithelial cells, semen and forensic stains for PCR. Biotechniques. 25: 588-592.

Sambrook, A., Frintsch, B.F. \& Maniatis T. (1989). Mo- lecular Cloning: A Laboratory Manual. New York: Cold Spring Harbor Laboratory Press. 
Shibata, D.K., Arnheim, N. \& Martin, W.J. (1988). Detec- tion of human papilloma virus in paraffin- embedded tissue using the polymerase chain reaction. J Exp Med. 167: 225-230.

Smith, K., Diggle, M.A. \& Clarke, C.S. (2003). Compari- son of commercial DNA extraction kits for extraction of bacterial genomic DNA from whole-blood samples. J Clin Microbiol. 41: 2440-2443.

Smith, K., Diggle, M.A. \& Clarke, S.C. (2003). Compari- son of commercial DNA extraction kits for extraction of bacterial genomic DNA from whole-blood samples. J Clin Microbiol. 41: 2440-2443.

Tell, L.A., Foley, J., Needham, M.L. \& Walker, R.L. (2003). Comparison of four rapid DNA extraction techniques for conventional polymerase chain reaction testing of three Mycobacteri- um spp. that affect birds. Avian Dis. 47: 1486-1490.

Tripathi, G.R., (2015). DNA analysis for the causes of blood anemia in fertility aged women of Nepal. A research report submitted to the Nepal Health Research Council, Ministry of Health, Government of Nepal.

Zhu, K., Jin, H., Ma, Y., Ren, Z., Xiao, C., He, Z., Zhang, F. \& Zhu, Q. (2005). Wang B: A continuous ther- mal lysis procedure for the large-scale prepa- ration of plasmid DNA. J Biotechnol. 118: 257-264. 